\title{
The emergence and scope of the human right to health
}

\section{Citation}

Marks, Stephen P. 2013. The Emergence and Scope of the Human Right to Health. In Advancing the Human Right to Health, ed. José M. Zuniga, Stephen P. Marks and Lawrence 0. Gostin: 3-23. Oxford: Oxford University Press.

\section{Published Version}

doi:10.1093/acprof:0so/9780199661619.003.0001

\section{Permanent link}

http://nrs.harvard.edu/urn-3:HUL.InstRepos:29429086

\section{Terms of Use}

This article was downloaded from Harvard University's DASH repository, and is made available under the terms and conditions applicable to Open Access Policy Articles, as set forth at http:// nrs.harvard.edu/urn-3:HUL.InstRepos:dash.current.terms-of-use\#OAP

\section{Share Your Story}

The Harvard community has made this article openly available.

Please share how this access benefits you. Submit a story.

\section{Accessibility}




\title{
Chapter 1. The Emergence and Scope of the Human Right to Health
}

[José M. Zuniga, Stephen P. Marks and Lawrence O. Gostin, (eds.), Advancing the Human Right to Health, Oxford University Press, 2013, pp. 3-23.]

\author{
Professor Stephen P. Marks \\ Harvard University
}

\section{Outline}

I. Introduction ..................................................................................................... 1

II. The emergence of health in the corpus of international human rights ........... 2

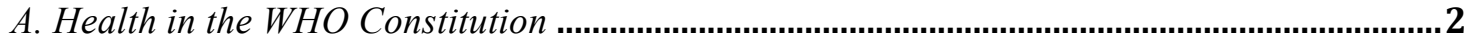

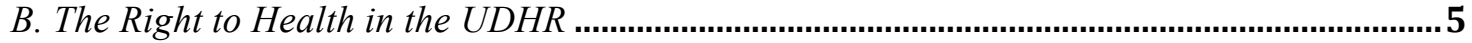

C. Health in the UN human rights treaty system ...............................................................6

D. The Right to Health in the regional treaty system ...................................................................

III. The normative content of the right to health ................................................... 9

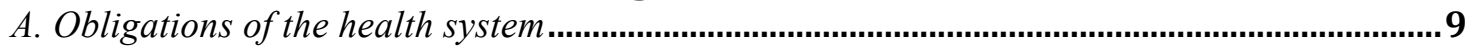

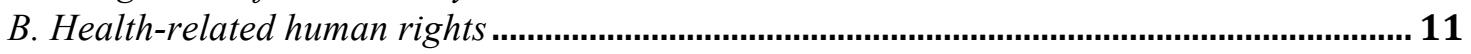

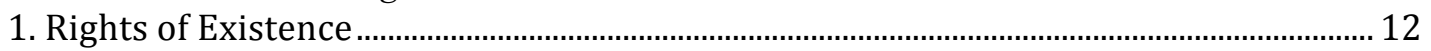

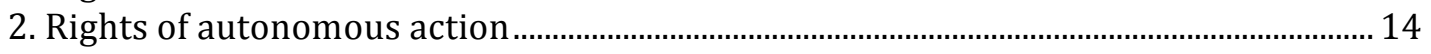

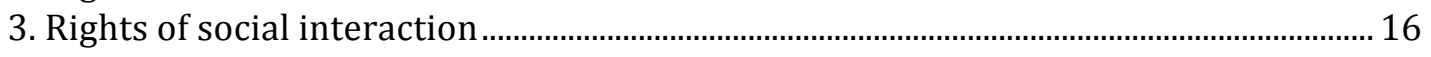

IV. Means and methods implementing the right to health ................................ 19

A. Promotion (information and education, institutions, further standard-setting) .................... 20

B. Protection (monitoring and evaluation, complaints and litigation) ........................................ 20

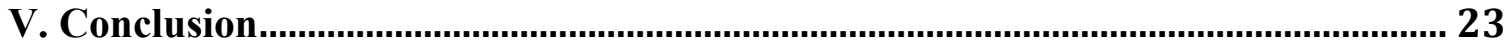

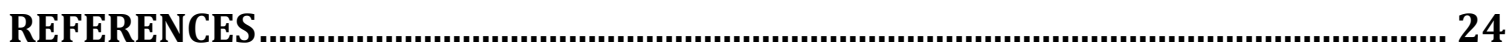

\section{Introduction}

The right to health occupies a prominent place among the internationally recognized human rights, although its formulation and further elaboration are relatively recent. In this chapter, I examine the emergence and scope of the right to health in the corpus of international human rights norms.

Human rights, including the right to health, constitute a set of norms governing the treatment by states and non-state actors of individuals and groups on the basis of ethical principles incorporated into national and international legal systems. Thus, the source of human rights is to be found in the norm-creating process of national and international legal systems, which provides the formal 
validation of normative positions. The positions emerge from ethical reasoning in moral philosophy or religious faith - what we might term the deeper origins of human rights-or from political claims, which emerge from social mobilization. In plain language, this means that the right to health has emerged from a process of people successfully advocating and eventually obtaining formal recognition in law and policy that they are entitled to-and the state must ensure that they have-an opportunity to lead a healthy life.

The process of formal recognition of the right is incomplete and involves many institutions and reference documents, which are described in Part II on the emergence of the right. What elements of a healthy life are properly included in its normative content is the subject of Part III. How the right can be advanced is summarized in Part IV on the means and methods employed to translate the normative aspirations of this right into justiciable and enforceable legally-binding obligations. Many more specifics on the content of the right and the efforts to advance its realization at the national and international levels are provided throughout this book. The conclusion in Part $\mathrm{V}$ will relate the definitional issues discussed to the broader range of issues explored in other chapters.

\section{The emergence of health in the corpus of international human rights}

\section{A. Health in the WHO Constitution}

The early formulation of norms we characterize today as human rights is inseparable from historical and philosophical manifestations of human striving for justice. The deepest origin of human rights no doubt derives from basic human instincts of survival of the species and manifestations of empathy and altruism that evolutionary biology is only beginning to explain. (Wilson, 2012; Harris 2010) In legend, literature, religion and political thought, justice and eventually the concept of human rights became socially constructed over time into complex webs of social interaction striving toward a social order in which human beings are treated fairly as individuals and collectivities. The best-known histories of the human rights movement (Ishay 2008, Loren 1998, Lauterpacht 1950), tend to begin with the ancient religions and societies.

The current catalogue of human rights-at least those enumerated in the International Bill of Human Rights-consists of some fifty normative propositions, expanded by a score of specialized United Nations (UN) treaties, a half-dozen regional human rights treaties, and hundreds of international norms elaborated in the fields of labor, refugees, armed conflict, and criminal law. This corpus of human rights law, enriched by declarations, programs of action and other formulations of human rights in the process of becoming legally binding, is the source of the norms that properly fall with the category of international human rights. This body of internationally recognized norms is one of the responses of the community of nations to the horrors of World War II and the commitment to constructing a world order "to save succeeding generations from the scourge of war, which twice in our lifetime has brought untold sorrow to mankind." (UN Charter, 1945) The setting up of a system of UN agencies, 
such as the World Health Organization (WHO), was another. The prevailing zeitgeist for these normative and institutional developments explains the way health was defined and recognized as a human right by the WHO.

Health is defined in the Preamble to the 1946 Constitution of the World Health Organization as "a state of complete physical, mental and social well-being and not merely the absence of disease or infirmity". The preamble further affirms, "the enjoyment of the highest attainable standard of health is one of the fundamental rights of every human being without distinction of race, religion, political belief, economic or social condition." The WHO definition was broadened by the 1978 Declaration of Alma-Ata on Primary Health Care, which strongly reaffirmed the definition calling it "a fundamental human right" and adding "that the attainment of the highest possible level of health is a most important world-wide social goal whose realization requires the action of many other social and economic sectors in addition to the health sector." (WHO, 1978) The Declaration of Alma-Ata also contains a pledge to progressively develop comprehensive health care systems to ensure effective and equitable distribution of resources for maintaining health. It has been regretted that, despite this language in the Constitution, "WHO intentionally neglected human rights discourse during crucial years in the development and implementation of the right to health, [and] ... did so to the detriment of public health." (Meier, 2010: 2)

The WHO definition, understandable in the context of the immediate aftermath of World War II, was not considered contentious when proposed to the Preparatory Committee that drafted the Constitution. (Tobin, 2012: 28) Apparently the wording reflects the language of Henry Sigerist in his books Medicine and Human Welfare (1941) and Civilization and Disease (1943), which influenced his friend, the Yugoslav delegate Andrija Štampar, who played a significant role in the drafting. (Bok, 2008: 594) It has been highly contested over the years and several alternatives have been proposed since. Sisella Bok, in her perceptive analysis of the philosophical issues surrounding the WHO definition, finds this a "mystifying definition" and argues that the terms "complete" and "social" and even "well-being" contribute to the confusion, which was only prolonged by the Alma Ata Declaration. (Bok, 2008: 596) She quite helpfully points out that Article 12 of the Covenant, discussed below, while drawing on the WHO definition, departs from it by avoiding the terms "complete," "social" and "well-being" (Bok, 2008: 595). This is true for most other formulations of the right, with the exceptions of the relevant Inter-American treaty (which reproduces the exact words of the WHO definition), and an African Charter, which adds "spiritual health", a proposal which failed in the WHO in 1999. (Bok, 2008: 595) However, as I will argue in the section below on health-related human rights, even the term "social" can be helpful if dealt with from a human rights perspective (as proposed) rather than in the sense of the social engineering of totalitarian regimes, as Bok correctly warns against.

This clarification is important for understanding the meaning of the right to health in two ways. First, the critique of the nebulous character of the WHO definition of health, which is of little operational value, does not apply to the definition and interpretation of the right to health as it has evolved into an operational concept. 
Second, proposals to narrow the definition of health to a biostatistical conception are not necessarily useful for the right to health. For example, Norman Daniels correctly notes that the WHO definition leads to the misconception that health is "all there is to well-being or happiness." (Daniels, 2008; 37) However, his insistence on an alternative definition focusing on the normal functioning of our species measured by biomedical statistics is of very limited value to promoting the human right to health, although it may be quite useful for some aspects of public health practice. The intent of the WHO definition was to expand from the negative definition (absence of disease) to positive aspects, consistent with the emerging focus on "social medicine" in the 1940s. (Meier 2010: 6) The human rights texts use one version or another of "highest attainable standard of physical and mental health", leaving to subsequent elaboration the specifics of what it takes to reach that standard and what features of health will be considered relevant.

The biostatistical conception has the advantage of using objective biological definitions of a healthy organism, without excluding issues of equity or social determinants, which can be raised in the context of health policy but are not definitional to health. From a human rights perspective, the concept of "the enjoyment of the highest attainable standard of health" is preferable to the biostatistical conception used by Daniels and others for several reasons. First the biostatistical conception relates to the measurement of an individual's health but says little about what a human rights-inspired health policy should strive to achieve for the population. The appeal is strong to rely on a biostatistical definition because it can be measured and interventions can be identified. However, it is only partially useful for bodies entrusted with assessing compliance with the right to health. It is certainly helpful for members of the Committee on Economic, Social and Cultural Rights (CESCR), for example, to receive data on infant mortality, maternal mortality, life expectancy, and all the other markers of healthy organisms. However, their determination of adequacy of government efforts to realize the right to health would be hampered considerably if all they were interested in were these biostatistical markers. The Committee's guidelines focus primarily on measures taken to ensure health outcomes rather than the statistical data relating to those outcomes. (UN 2009) Monitoring bodies also need to look at the health system, inequalities, and the various dimensions of the normative content of the right as discussed in Part III below.

Similarly, Backman et al. demonstrated in their Lancet article the value of an assessment of health systems and the right to health by applying "a manageable set of indicators" to 194 countries with the purpose, among others, of deepening "the understanding of the important role of health data and indicators in relation to the progressive realization of the right to health." (Backman et al, 2008: 2054) Of the 72 indicators selected, only a half-dozen would be considered as based on a biological definition of a healthy organism (such as infant mortality rate, maternal mortality ratio, and life expectancy). The vast majority of the indicators related to recognition of the right to health, non-discrimination, health information, participation, financing, awareness, and accountability. The aim, it should be stressed, of the CESCR and the 
Lancet study is to assess compliance with the right to health, not the health of a person or population.

Second, reliance on statistical measures of conformity to "normal" functioning of the organism may in fact lead to positions that are antithetical to human rights. For example, if a statistically significant norm for biological health includes sexual drive directed toward reproduction as "normal", then individuals whose sexual drive is directed exclusively or mainly towards same-sex relations, would be "unhealthy" biostatistically and therefore pathological. From a human rights perspective, persons preferring same-sex relations and who are supported by the health system and other elements of society in their sexual orientation would be considered-other conditions being equal-healthy physically, mentally and socially. Persons with disabilities both physical and mental fall below the biostatistical standard for being "healthy" but from a human rights perspective can be considered as enjoying the right to physical, mental and social health if the health system meets their special needs. The deviation from the statistical norm would not be relevant to the realization of the right to health. Of course, Daniels acknowledges that for some people "the functional deficit does not compromise health at all, even though it clearly involves what medicine considers pathology." (Daniels, 2008:36) His point, however, is that the definition of health should be expanded from the absences of disease to the absence of pathology, including disability and injury. His view is that "health is normal functioning of our species" based on "scientific methods of the biomedical sciences to characterize pathology, as well as on our ongoing understanding of epidemiology, including social epidemiology, to clarify what we need to function normally." (Daniels, 2008: 37)

In sum, while the WHO definition raises complex philosophical issues, it has been used without the confusing concepts of "complete" and "well-being", for further normative and practical elaboration of the right to health. The arguments for a narrow statistical definition of health as absence of pathology do not carry over into the instrumental value of a broader definition of health in the context of the right to health, as the experience with the definition of this right after the WHO Constitution demonstrates.

\section{B. The Right to Health in the UDHR}

The right to health resurfaced two years later as a component of the right to an adequate standard of living in article 25(1) of the 1948 Universal Declaration of Human Rights (UDHR): "Everyone has the right to a standard of living adequate for the health of himself and of his family, including food, clothing, housing and medical care and necessary social services, and the right to security in the event of unemployment, sickness, disability, widowhood, old age or other lack of livelihood in circumstances beyond his control." This wording was proposed by the Latin American delegations to the drafting committee of the Commission on Human Rights with the UN secretariat playing a major role. (Morsink 1999, 192) According to Johannes Morsink's analysis of the drafting of the UDHR, the secretariat drew on "the Latin American socialist tradition" and some thirteen national constitutions containing this right (Morsink 1999, 192) and proposed a separate article on the 
right to medical care. Citing an Indian proposal for an article reading "every human being has the right to health," he notes that former colonies were more willing to recognize such a right than North Atlantic countries, whose constitutions tended not to recognize the right to health. Nevertheless, the drafting committee adopted a U.S. proposal, drawing on the WHO constitution, stating, "Everyone, without distinction of economic and social condition, has the right to the highest attainable standard of health. The responsibility of the State and community for the health and safety of its peoples can be fulfilled only by provision of adequate health and social measures." (Morsink 1999, 194) However, the final draft-after several intermediate versions-added the three rights to food, clothing and housing "seen as means to the end of health care," and "necessary social services." (Morsink 1999, 198)

\section{Health in the UN human rights treaty system}

From the initial formulations in the WHO Constitutions and the UDHR, the right to health was included in the major UN human rights treaties adopted since, primarily the International Covenant on Economic, Social and Cultural Rights (ICESCR) of 1966. By the time the UN started transforming the UDHR into a treaty, the Cold War altered the political landscape. The broadening of the definition and the illustrative examples of steps states should take to realize the right were the result of WHO's "significant role in the initial drafting of Article 12". (Alston: 88) It was the Director-General of WHO who submitted in April 1951 a draft text on the right to health to the Commission on Human Rights, including the broad WHO definition of health, as well as measures relating to the social determinants of health and the responsibilities of government. (Meier 2010, 15) The approach to the drafting of the ICESCR differed from that of the UDHR in treating this right on its own rather than within an enumeration of components of the right to an adequate standard of living. The second salient feature was to go well beyond health care to cover a "positive definition of health." (Meier 2010, 15) The third was to enumerate illustrative steps to be taken to realize this right. Working with the International Labour Organisation (ILO) delegate, the WHO delegate convinced the drafters to include the illustrative steps in paragraph 2 of Article 12. (Alston: 88) Unlike the ILO, which had long experience with its drafting and monitoring its own standards and preferred that the Covenant should express each right in a brief clause, WHO felt the need to push for more detailed provisions regarding the scope and substance of the right to health. (Alston: 85)

After a change in leadership at the WHO in 1953, the organization ceased to play an active role in the drafting of the Covenant article, reflecting, as Meier explains, the shift in WHO's discourse on health "from the social medicine focus on human rights and ... toward curative health care ... a biomedical vision of health, emphasizing antibiotics medical technologies, and private urban hospitals as a means to achieve economic growth." (Meier 2010, 25-26) As a result, WHO declined even to comment on the evolving draft right to health article of the Covenant and by 1957 "WHO had lost credibility to effect change within the U.N. Secretariat and among state delegations." (Meier 2010, 28) For example, it did not prevent the 
deletion of the definition of health drawn from the WHO constitution and of the term "social", or the weakening of other provisions. Nor did it contribute to the work of the Commission on implementation measures in the 1960s. (Alston: 88) After the adoption of the final text in 1966, Meier explains, "WHO claimed no ownership or responsibility over the new Covenant's obligations on health." (Meier 2010, 31) The final text of Article 12, consisting of 118 words, nevertheless, draws heavily on the initial contribution of WHO before 1953 and remains the most detailed in the Covenant.

The right to health in Article 12 is in two parts: a general affirmation in paragraph 1 and a partial enumeration of steps in paragraph 2 . The general part defines the right as "the right of everyone to the enjoyment of the highest attainable standard of physical and mental health". Then comes an illustrative, non-exhaustive list of five "steps to be taken ... to achieve the full realization of this right", namely, "(a) The provision for the reduction of the stillbirth-rate and of infant mortality and for the healthy development of the child; (b) The improvement of all aspects of environmental and industrial hygiene; (c) The prevention, treatment and control of epidemic, endemic, occupational and other diseases; (d) The creation of conditions which would assure to all medical service and medical attention in the event of sickness".

Variations on this definition are found in the major UN human rights treaties, specifically:

\begin{tabular}{|l|l|}
\hline $\begin{array}{l}\text { International Convention on the } \\
\text { Elimination of All Forms of Racial } \\
\text { Discrimination of 1965 (CERD) }\end{array}$ & $\begin{array}{l}\text { "The right to public health, medical } \\
\text { care, social security and social } \\
\text { services" (Article 5 (e) (iv)) }\end{array}$ \\
\hline $\begin{array}{l}\text { Convention on the Elimination of All } \\
\text { Forms of Discrimination against } \\
\text { Women of } 1979 \text { (CEDAW) }\end{array}$ & $\begin{array}{l}\text { "the right to protection of health and to } \\
\text { safety in working conditions, including } \\
\text { the safeguarding of the function of } \\
\text { reproduction...[and] to eliminate } \\
\text { discrimination against women in the } \\
\text { field of health care in order to ensure, } \\
\text { on a basis of equality of men and } \\
\text { women, access to health care services, } \\
\text { including those related to family } \\
\text { planning [and] ensure to women } \\
\text { appropriate services in connection } \\
\text { with pregnancy, confinement and the } \\
\text { post-natal period, granting free } \\
\text { services where necessary, as well as } \\
\text { adequate nutrition during pregnancy } \\
\text { and lactation" (Articles 11.1 (f) and 12) }\end{array}$ \\
\hline $\begin{array}{l}\text { Convention on the Rights of the Child } \\
\text { of } 1989 \text { (CRC) }\end{array}$ & $\begin{array}{l}\text { "the right of the child to the enjoyment } \\
\text { of the highest attainable standard of }\end{array}$ \\
\hline
\end{tabular}




\begin{tabular}{|c|c|}
\hline & $\begin{array}{l}\text { health and to facilities for the } \\
\text { treatment of illness and rehabilitation } \\
\text { of health...", followed by an } \\
\text { enumeration of six measures to } \\
\text { "pursue full implementation of this } \\
\text { right" (Article 24) }\end{array}$ \\
\hline $\begin{array}{l}\text { Convention on the Rights of Persons } \\
\text { with Disabilities of } 2006 \text { (CRPD) }\end{array}$ & $\begin{array}{l}\text { "...persons with disabilities have the } \\
\text { right to the enjoyment of the highest } \\
\text { attainable standard of health without } \\
\text { discrimination on the basis of } \\
\text { disability," followed by an enumeration } \\
\text { of six "measures to ensure access for } \\
\text { persons with disabilities to health } \\
\text { services that are gender-sensitive, } \\
\text { including health-related rehabilitation" } \\
\text { (Article 25) }\end{array}$ \\
\hline
\end{tabular}

\section{The Right to Health in the regional treaty system}

Regional human rights treaties also define the right to health. Article 11 of the European Social Charter of 1961 (as revised in 1996), stipulates states' obligation to take measures "to remove as far as possible the causes of ill-health; to provide advisory and educational facilities for the promotion of health and the encouragement of individual responsibility in matters of health; to prevent as far as possible epidemic, endemic and other diseases, as well as accidents;" and the duty "to ensure that any person who is without adequate resources and who is unable to secure such resources either by his own efforts or from other sources, in particular by benefits under a social security scheme, be granted adequate assistance, and, in case of sickness, the care necessitated by his condition". (European Social Charter, 1996) Article 16 of the African Charter on Human and Peoples' Rights of 1981 affirms "...the right to enjoy the best attainable state of physical and mental health [and the obligation of the state to] take the necessary measures to protect the health of their people and to ensure that they receive medical attention when they are sick." Article 14 of the African Charter on the Rights and Welfare of the Child of 1990 stipulates: "1. Every child shall have the right to enjoy the best attainable state of physical, mental and spiritual health," with paragraph 2 listing ten measures toward this end. Article 10 of the Additional Protocol to the American Convention on Human Rights in the Area of Economic, Social and Cultural Rights of 1988 states that "1. Everyone shall have the right to health, understood to mean the enjoyment of the highest level of physical, mental and social well-being" and lists in paragraph 2 six measures to ensure this right. This pattern was followed in Article 39 of the Arab Charter on Human Rights (2004), which entered into force in 2008 and stipulates in paragraph 1: "The States parties recognize the right of every member of society to the enjoyment of the highest attainable standard of physical and mental health and 
the right of the citizen to free basic health-care services and to have access to medical facilities without discrimination of any kind;" and in paragraph 2 the following measures to be taken by States parties: "(a) Development of basic healthcare services and the guaranteeing of free and easy access to the centres that provide these services, regardless of geographical location or economic status; (b) Efforts to control disease by means of prevention and cure in order to reduce the morality rate; (c) Promotion of health awareness and health education; (d) Suppression of traditional practices which are harmful to the health of the individual; (e) Provision of the basic nutrition and safe drinking water for all; (f) Combating environmental pollution and providing proper sanitation systems; (g) Combating drugs, psychotropic substances, smoking and substances that are damaging to health."

Although case law is not very abundant under these regional treaties, it is expanding through the African Commission on Human and Peoples' Rights (for example, ACHPR 2001-2002, ACHPR 2002-2003; Chirwa, 2008: 330-331), the InterAmerican Commission on Human Rights (for example, IACHR 2001; Melish, 2008: 351-355, 362-363), the European Court of Human Rights (for example, ECtHR 1994; ECtHR 2008; Clements \& Simmons, 2008: 417-420), and the European Committee of Social Rights (ECSR 2009; Khaliq \& Churchill, 2008: 435-437). As noted by Malcolm Langford, "the number of avenues for social rights litigation [including the right to health] at the regional and international level expanded" with the establishment of these regional bodies. (Langford 2008: 8)

\section{The normative content of the right to health}

While one can theorize on what the right to health entails, a consensus has merged over the past twenty years that the Committee on Economic, Social and Cultural Rights (created to monitor the ICESCR) by and large captured the essential elements in its General Comment No. 14 on the Right to Health (CESCR 2000). The right to health does not mean the right to be healthy, the CESCR explains, since being healthy is determined in part by health care, but also by genetic predisposition and social factors. (CESCR 2000, para. 8). Thus, the scope of the right to health covers both specific elements of the health system (section A) and the realization of other human rights that contribute to health (section B).

\section{A. Obligations of the health system}

Since the essence of the right to health is access to the conditions necessary for the realization of healthy lives, it is the duty of the state to ensure those conditions, whether through a regulated market or through government services. In this regard, the CESCR provided a framework that has been widely accepted to identify what is expected to ensure that health facilities, goods and services, including the underlying determinants of health, are available, accessible, acceptable and of good quality (CESCR 2000, para. 12). The Committee explains each term. "Availability" refers to facilities, goods and services not only of the health system (such as hospitals, clinics, trained medical and professional personnel, medecines, 
etc.) but also the underlying determinants of health (such as safe and potable drinking water and adequate sanitation). The "accessibility" requirement has four overlapping dimensions: accessible without discrimination, physically accessible, economically accessible (i.e., affordable), and accessible health-related information. The "acceptability" dimension refers to respect for medical ethics and cultural sensitivities. Finally the "quality of care" dimension relates to health facilities, goods and services being scientifically and medically appropriate and of good quality (such as "skilled medical personnel, scientifically approved and unexpired drugs and hospital equipment, safe and potable water, and adequate sanitation"). (CESCR 2000, para. 12(d))

These four dimensions are not very different from-in fact they are surprisingly congruent with - the dimensions of the practice of public health. As Gruskin and Tarantola put it, "the added value of a human rights approach to health is in systematizing attention to these issues, requiring that benchmarks and targets be set to guarantee that any targets set are realized progressively, and ensuring transparency and accountability and for what decisions are made and their ultimate outcomes." (Gruskin and Tarantola 2008, 140)

Expanding on theses dimensions of the right to health, the CESCR enumerates what is expected of governments to comply with their obligations to respect, protect and fulfill the right to health. These three obligations (with the third sometimes expanded into the obligations to promote and to provide) have become the standard approach of treaty bodies and thematic rapporteurs. They have a distinct value for health practitioners, who quite understandably wonder what the right to health would require them to do differently than they already are doing to promote improvements in health delivery with a sensitivity to issues of equity and social justice, not uncommon among health professionals.

While these obligations are to be met within the context of progressive realization of the right to health, the CESCR took the bold step of enumerating a subset of obligations belonging to a "core minimum", which is not subject to progressive realization.

(1) to ensure the right of access to health facilities, goods and services on a non-discriminatory basis, especially for vulnerable or marginalized groups; (2) to ensure access to the minimum essential food which is sufficient, nutritionally adequate and safe, to ensure freedom from hunger to everyone; (3) to ensure access to basic shelter, housing and sanitation, and an adequate supply of safe and potable water; (4) to provide essential drugs, ... defined by WHO's Action Programme on Essential Drugs; (5) to ensure equitable distribution of all health facilities, goods and services; (6) to adopt and implement a national public health strategy and plan of action, on the basis of epidemiological evidence, addressing the health concerns of the whole population....(CESCR, 2000, para. 43, emphasis added) 
It is worth quoting in full what the CESCR identified as how the national plan of action should be devised and reviewed, namely, "on the basis of a participatory and transparent process." Moreover, these plans "shall include methods, such as right to health indicators and benchmarks, by which progress can be closely monitored." Finally, the strategy and plan of action "shall give particular attention to all vulnerable or marginalized groups."

The CESCR added a set of "obligations of comparable priority" including:

(1) to ensure reproductive, maternal (pre-natal as well as post-natal) and child health care; (2) to provide immunization against the community's major infectious diseases; (3) to take measures to prevent, treat and control epidemic and endemic diseases; (4) to provide education and access to information concerning the main health problems in the community, including methods of preventing and controlling them; and (5) to provide appropriate training for health personnel, including education on health and human rights. (CESCR, 2000, para. 44)

From a legal perspective, governments that fail to meet those core (and equivalent) obligations are not in compliance with the Covenant; from the public health perspective, these core obligations are indicative of priorities for the health system based on the right to health. Beyond these core obligations relating to health care and the underlying determinants of health, the normative content of the right to health directly involved with the health system, concern, as the first Special Rapporteur pointed out, freedoms, such as "the right to control one's health, including the right to be free from non-consensual medical treatment and experimentation." Finally, the normative content of the right to health dependent on the health system includes specific entitlements in such areas as maternal, child and reproductive health; occupational health; and prevention, treatment, and control of diseases, including access to essential medicines. (UN 2003, paras. 22-24) These features of the normative content are expanded by other health-related human rights.

\section{B. Health-related human rights}

The CESCR listed the following 14 human rights as "integral components of the right to health": "the rights to food, housing, work, education, human dignity, life, non-discrimination, equality, the prohibition against torture, privacy, access to information, and the freedoms of association, assembly and movement." (CESCR 2000, para. 3) Human rights have been categorized in various ways, the most common being to distinguish economic, social and cultural from civil and political rights, although the contemporary value of such categorization has been questioned. (Marks 2009) For the purpose of relating the core internationally-recognized human rights to the realization of health and well-being, it is proposed here to group human rights in to three categories, corresponding to the three domains covered in the WHO definition (physical, mental, and social) translated into concepts that are meaningful in moral philosophy and human rights. Physical health overlaps with 
rights concerning the physical existence and integrity of humans ("rights of existence"); mental health is broadened here to cover those rights that protect the autonomy of thought and action of individuals ("rights of autonomous action"), it being understood that this category is quite different from prevention and treatment of mental illness; and social well-being, that is, those rights that involve social interactions of individuals and groups from the family to the political, cultural and international communities ("rights of social interaction"). These are not tight categories fitting into the definition of health, but rather a way of grouping healthrelated human rights that is intended to be meaningful from the perspective of physical, mental and social well-being. The purpose of including these three categories in a discussion of the scope of the right to health is to draw attention to the fact that deprivations of physical integrity, restrictions on autonomous action and reduced opportunities for social interaction all have an impact on the full realization of the right to health while often constituting human rights violations themselves.

\section{Rights of Existence}

Foremost among the human rights relating to physical integrity is the right to not be arbitrarily deprived of life. As defined internationally, the right to life does not ban death resulting from lawful acts of warfare or capital punishment, although international humanitarian law limits the former and newer protocols and regional conventions, supported by UN resolutions and social movements, define the death penalty as a violation of human rights. (Schabas, 1998) The right to death with dignity is sometimes claimed as the human rights grounding for domestic legislation on the subject. (Biggs 2001) Although there is no explicit international human right to death, some scholars construe this right from various recognized rights, such as the rights to dignity and, freedom from cruel inhuman or degrading treatment. (Paust 1995)

Another controversial aspect of the right to life relevant to the right to health is the tension between the claim that it includes the right to life of the fetus from the moment of conception and the claim that reproductive rights of the pregnant woman include the right to voluntary termination of her pregnancy. The right to an abortion is recognized in various national legal systems but not explicitly in international human rights due in large part to opposition by Catholic and Islamic countries. As Jonathan Wolff summarized the debate, "many have argued from a religious perspective that contraception, and even more so, abortion, are morally unacceptable, and so not only is it right to restrict access to services and information about them, but it is even wrong to offer them." (Wolff 2012, 31) This issue is authoritatively discussed in another chapter in this volume. (Yamin 2013)

Physical integrity is protected in various ways. Special standards, developed in the context of the UN's work on crime prevention and treatment of offenders, apply to the treatment of detainees, as well as the rights and responsibilities of lawyers, prosecutors, judges, and law enforcement officers. For example, the UN Standard Minimum Rules for the Treatment of Prisoners stipulates that "[a]ll 
accommodation provided for the use of prisoners ... shall meet all requirements of health, due regard being paid to climatic conditions and particularly to cubic content of air, minimum floor space, lighting, heating and ventilation." (UN, 1955, para. 22) With regard to medical services, the Standard Minimum Rules require that they "should be organized in close relationship to the general health administration of the community or nation" and make special provision for mental health, dental services, obstetric and pediatric care for incarcerated women, prevention of spread of infectious disease, and the role of the medical officer with regard to food, hygiene, sanitation and similar conditions of incarceration. (UN, 1955, paras. 23-25) This issue is addressed in greater detail in another chapter of this publication. (Mariner and Schleifer 2013)

More recent standard-setting activity has focused on impunity, accountability of high government officials, and compensation for victims of human rights violations. Special treaties and procedures exist for torture, disappearance, and summary and extra-judicial execution. (Bochenek 2013)

Political violence resulting in massive harm to populations entails a wide range of human rights violations affecting the right to health. Certain acts of grievous harm to physical and mental integrity, when "part of a widespread or systematic attack directed against any civilian population," may constitute crimes against humanity, punishable under international law. The Rome Statute of the International Criminal Court of July 17, 1998 (which entered into force on 1 July 2002) lists the following acts as falling within this particular violation of human rights:

(a) Murder; (b) Extermination; (c) Enslavement; (d) Deportation or forcible transfer of population; (e) Imprisonment or other severe deprivation of physical liberty in violation of fundamental rules of international law; (f) Torture; (g) Rape, sexual slavery, enforced prostitution, forced pregnancy, enforced sterilization, or any other form of sexual violence of comparable gravity; (h) Persecution against any identifiable group or collectivity on political, racial, national, ethnic, cultural, religious, gender ..., or other grounds that are universally recognized as impermissible under international law, in connection with any act referred to in this paragraph or any crime within the jurisdiction of the Court; (i) Enforced disappearance of persons; (j) The crime of apartheid; (k) Other inhuman acts of a similar character intentionally causing great suffering, or serious injury to body or to mental or physical health. (Rome Statute 1998, Article 7)

Special treaties and procedures for prevention and repression of certain human rights violations considered as international crimes-such as genocide, torture, slavery, racial discrimination and various forms of terrorism-are part of human rights law, as well as of international criminal law and international 
humanitarian law. International humanitarian law, established to protect victims of armed conflict (injured and shipwrecked combatants, prisoners of war and civilian populations notably under occupation) was codified in the four Geneva Conventions of August 12, 1949, and the Additional Protocols of 1977 and is sometimes referred to as the law of human rights in times of armed conflict. (See also, Sutton 2013)

Disability rights were not included in the International Bill of Human Rights but specific human rights standards have been developed for persons with disabilities and mental illness, in particular, the Convention on the Rights of Persons with Disabilities, adopted in 2006, with extensive provisions on health in Article 25.

The right to "a standard of living adequate for the health and well-being" of oneself and one's family was defined in the Universal Declaration of Human Rights as including "food, clothing, housing and medical care and necessary social services," as well as "the right to security in the event of unemployment, sickness, disability, widowhood, old age or other lack of livelihood in circumstances beyond [one's] control." Subsequently, the rights to health, work, safe and healthy working conditions (occupational health), adequate food and protection from malnutrition and famine, adequate housing, and social security (that is, a regime covering longterm disability, old age, unemployment and other conditions) have been further elaborated. The rights to work and to decent conditions of work have been the responsibility of the ILO since 1919, and specific rules have been developed through some 200 ILO conventions and recommendations, constituting a highly developed sub-field of human rights. The other rights relating to an adequate living standard have also been expanded upon by treaties, international conferences and summits, and the work of Special Rapporteurs and treaty bodies. This broad range of human rights norms covers the essential components of the social determinants of health. In this regard, the World Conference on Social Determinants of Health in 2011 discussed "using the human rights approach and tools to address health inequities and strengthen the implementation of actions in the social determinants framework." (WHO 2011, 36)

Complementing these rights of physical existence and integrity, human rights protecting autonomy of action also contribute to the right to health.

2. Rights of autonomous action

Several human rights fall within the category of rights that preserve and protect the human value of each person and his or her autonomy and freedom of action. Dignity tends to be mentioned as both the basis for all human rights and a right per se. If dignity means the worth and honor due to any human being in accordance with the social context, in which failure to respect dignity results in humiliation, then the right implies measures to eliminate both acts and omissions, such as discrimination, mistreatment, or lack of an adequate standard of living. However, some courts have applied an objective concept of dignity according to which certain acts (such as making a spectacle of a disability) violate the right to dignity even if consented to by the alleged victim. 
The great civil liberties-freedom of oral and written expression, freedom of conscience, opinion, religion or belief-as well as rights to a fair hearing and an effective remedy for violations of human rights, and protection of privacy in domicile and correspondence, all support the autonomy of individuals to act without interference from the state or others. The implications for mental health of these freedoms are easy to identify. Similarly, freedom from arbitrary detention or arrest, from torture or other forms of cruel, inhuman or degrading punishment or treatment, and humane conditions of detention for those legally deprived of their liberty, have obvious implications for physical and mental health. Human rights standards in UN and regional texts provide the definitions and means of redress for these rights. A separate but related human right is that of informed consent to medical experimentation, which was included in post-1945 enumerations of rights due to the abhorrent abuse of that right during World War II.

Equality and non-discrimination are human rights that are at the same time principles for the application of all other human rights, because they require that all persons be treated equally in the enjoyment of their human rights and that measures be taken to remove discriminatory practices on prohibited grounds. According to the CESCR, the first dimension of accessibility of the right to health is non-discrimination, according to which "health facilities, goods and services must be accessible to all, especially the most vulnerable or marginalized sections of the population, in law and in fact, without discrimination on any of the prohibited grounds" (CESCR, 2000, para.12(b)). The Committee further reminds States parties that the "Covenant proscribes any discrimination in access to health care and underlying determinants of health, as well as to means and entitlements for their procurement, on the grounds of race, colour, sex, language, religion, political or other opinion, national or social origin, property, birth, physical or mental disability, health status (including HIV/AIDS), sexual orientation and civil, political, social or other status, which has the intention or effect of nullifying or impairing the equal enjoyment or exercise of the right to health." (CESCR, 2000, para.18) It also stresses the protection of the vulnerable members of society "by the adoption of relatively low-cost targeted programmes." (CESCR, 2000, para.19)

Related to freedom of expression is the right to what is called the "moral and material interests" in any literary, artistic or scientific creation. Thus copyrights, patents and other intellectual property rights fall into this category of human rights to the extent that they relate to an individual's creative energies and products; however, intellectual property rights are less justified as "human rights" when owned by corporations and utilized to market products for return on investment, as confirmed by the CESCR in its 2005 General Comment No. 17. (UN, 2005; see also Marks and Benedict 2013)

Freedom of movement means the right to reside where one pleases, to leave any country, including one's own, and to return to one's country. The limitation on this right "necessary to protect ... public health ..." (ICCPR, Article 12 (3)) is the prime example of human rights accommodating the public health imperative of 
quarantining in times of epidemic. This limitation has been interpreted as allowing public health to be invoked "as a ground for limiting certain rights in order to allow a state to take measures dealing with a serious threat to the health of the population or individual members of the population. These measures must be specifically aimed at preventing disease or injury or providing care for the sick and injured." (UN 1984, para. 25) Public health may also be a justifiable ground for limiting international travel, for example, in times of pandemic influenza. (WHO 2007b)

The right to seek and enjoy asylum from persecution is also a human right, which has been developed and expanded by international refugee law, the practice of the UN High Commissioner for Refugees (UNHCR), and recent codes relating to internally displaced persons. This right, like many others, is not absolute: limitations may be imposed, for example, in times of epidemic, as long as certain safeguards, defined in human rights law, are observed.

\section{Rights of social interaction}

The third set of rights that are also determinants of health relate to the participation of individuals in their society. Social well-being-an element of health-relates to group rights, education, family, access to and participation in culture, political participation, gender and reproductive rights, the environment and development, all of which are the subject of specific human rights with health implications.

The basic human rights texts affirm a limited number of group rights, notably the rights of "peoples" to self-determination, that is, to "determine their political status and freely pursue their economic, social and cultural development" and to permanent sovereignty over natural resources. (ICCPR and ICESCR, Art. 1.) They also enumerate the rights of persons belonging to minorities to practice their religion, enjoy their culture and use their language. (ICCPR, Art. 27.) Indigenous peoples have defined rights that take into account their culture and special relation to the land. (UN, 2007) Health figures prominently among the concerns of minorities and indigenous peoples. For example, the Declaration on the Rights of Indigenous Peoples contains the following article on the right to health, in addition to several other health-related provisions relating to children, the environment and the right to development:

Article 24

1. Indigenous peoples have the right to their traditional medicines and to maintain their health practices, including the conservation of their vital medicinal plants, animals and minerals. Indigenous individuals also have the right to access, without any discrimination, to all social and health services.

2. Indigenous individuals have an equal right to the enjoyment of the highest attainable standard of physical and mental health. States shall take the necessary steps with a view to achieving progressively the full realization of this right. 
The right to education includes compulsory primary education, availability and accessibility of secondary education and equal access to higher education, and the role of parents in choosing their child's education institution. Of course, health education includes any learning experience that helps individuals and communities improve their health, and much of the essential knowledge and attitudes people need for healthy lives are communicated in an educational setting. In addition to the right to education, rights of the child have been codified in several instruments, primarily the 1989 Convention on the Rights of the Child (CRC), which makes "the best interest of the child" the primary consideration and defines rights relating to the child's identity, health and access to health care, expression of opinion, conditions of adoption, and protection from abuse, torture, capital punishment, and traditional practices prejudicial to the child's health.

Participation takes at least three forms in international human rights. Political participation includes the right to run for office and to vote in genuine and periodic elections. Cultural participation means primarily the right to participate in the cultural life of the community, whether through access to visual and performance art or through artistic creation and the protection of writers, artists and performers. The third meaning of participation relates to efforts to realize human rights whether through the exercise of freedom of association or protection of human rights defenders in accordance with a 1998 declaration, officially entitled Declaration on the Right and Responsibility of Individuals, Groups and Organs of Society to Promote and Protect Universally Recognized Human Rights and Fundamental Freedoms. All these types of participation contribute to the individual's integration into society and ability to influence his or her condition in society, all of which contribute to a healthy life.

Health issues loom large in human rights standard-setting and policy determination regarding gender, sexual and reproductive rights, which have profound implications for social interaction. The basic human rights texts have been supplemented by a specialized Convention on the Elimination of All Forms of Discrimination against Women (CEDAW) of 1979. Considerable advances in mainstreaming women's rights as human rights were made at the international conferences in Vienna (human rights, 1993), Cairo (population, 1994), and Beijing (women, 1995). Further developments have been made to deal with violence against women (through a 1993 Declaration and a Special Representative to study the problem) and traditional practices harmful to health, such as female genital cutting or mutilation, which States parties to the CRC and CEDAW agree to abolish (Article 24, CRC; Article 5, CEDAW) and about which WHO, the UN Children's Fund (UNICEF) and the UN Fund for Population Activities (UNFPA) issued a plan of action in 1994. Moreover, the committee monitoring CEDAW issued General Recommendation No. 14 on "Female Circumcision-FGM-Female Genital Mutilation" in 1990 calling on States parties to "take appropriate and effective measures with a view to eradicating the practice of female circumcision." 
Reproductive rights begin with "The right of men and women of marriageable age to marry and to found a family..." (ICCPR, art. 23(2)) which is closely related to the right of "men and women ... to decide freely and responsibly on the number and spacing of their children" (CEDAW, art. 16(1)(e)), and "to be informed and to have access to safe, effective, affordable and acceptable methods of family planning of their choice." (ICPD 1994) Various internationally-approved programs and plans of action have set out in considerable detail the specific ways in which this right can be realized and thus enhance health within the family setting and in the context of reproductive rights. (Yamin 2013)

In the same way that the distinction between civil and political, and economic, social and cultural rights is losing its relevance in the post-Cold War era (Marks, 2009), so too is the third category of solidarity or third generation rights less helpful as a distinct category than it was twenty years ago. (Marks 1981; Alston 2001) The "third generation" referred to a set of rights emerging after first generation civil and political rights and second generation economic, social and cultural rights, which reflect certain global values such as peace, a healthy environment, development, communication, humanitarian intervention or assistance and the like. Some governments and commentators wanted to raise these broad objectives to the level of human rights, notwithstanding the complex matter of defining the rights- and duty-holders and the precise obligations involved. Nevertheless, the rights to a healthy environment and to development, in particular, continue to have support and have been approved though UN resolutions and regional treaties, with a strong health component.

For example, in 1972 United Nations Conference on the Human Environment, which created the United Nations Environment Programme (UNEP), proclaimed in its Declaration of the United Nations Conference on the Human Environment that "man's environment, the natural and the man-made, are essential to his well-being and to the enjoyment of basic human rights-even the right to life itself." The African Charter provides that "all peoples shall have the right to a general satisfactory environment favorable to their development." (African Charter on Human and Peoples Rights, Article 24) The Draft Principles on Human Rights and the Environment, presented by the Special Rapporteur on Human Rights and the Environment, provides that "22. All States shall respect and ensure the right to a secure, healthy and ecologically sound environment." (UN, 1994) At the conclusion of the June 2012 United Nations Conference on Sustainable Development (Rio+20), the Heads of State and Government affirmed numerous times the importance of human rights and recognized "that health is a precondition for and an outcome and indicator of ... sustainable development", calling "for the full realization of the right to the enjoyment of the highest attainable standard of physical and mental health", including "universal health coverage to enhancing health, social cohesion and sustainable human and economic development." (General Assembly Resolution 66/288 The future we want, 27 July 2012, Annex, paras. 8, 9, 138 and 139.) In 2012, the Human Rights Council appointed the first Independent Expert on human rights obligations relating to the enjoyment of a safe, clean, healthy and sustainable 
environment, whose mandate includes contributing a human rights perspective to follow-up processes to Rio+20. (Human Rights Council, Resolution 19/10 of 22 March 2012)

As far as the right to development is concerned, the 1986 Declaration provides that "states should undertake, at the national level, all necessary measures for the realization of the right to development and shall ensure, inter alia, equality of opportunity for all in their access to... health services..." (Declaration on the Right to Development, Article 8) The high-level task force on the implementation of the right to development, established by the Commission on Human Rights in 2004, completed its work in 2010, including extensive analysis and proposals relating to the health dimensions of the right to development. (UN 2010)

This selection of rights relating to minority and indigenous rights, education, cultural and political participation, family, environment and development underscores the social dimensions of a healthy life, the realization of which improves many of the social determinants of health. These and all other dimensions of the right to health and health-related human rights remain lofty aspiration unless and until they become subject to obligations of duty-holders and mechanisms of accountability.

\section{Means and methods implementing the right to health}

The typical approach to public health consists in four steps: 1 . Identify the problem through the systematic collection of data; 2. Identify the causes of the problem using research on causes, risk factors, and potential interventions; 3. Design, implement and evaluate interventions; and 4. Test, monitor and evaluate effectiveness of promising interventions in diverse settings, and monitor and adapt them to enhance their impact and cost-effectiveness. This approach, familiar to public health professionals, differs from the typical process through which human rights objectives are met. When a right to health framework is introduced, it can complement the pubic health approach, but the means and methods are of a different nature.

The effective realization of the right to health, like any human right, depends on a process of norm elaboration and enforcement. In the domestic system, law is binding, and the courts and the police are available to use force to compel compliance. In the international human rights regime, the term "enforcement" refers to coerced compliance, while the more common term "implementation" refers to supervision, monitoring and general effort to hold duty-holders accountable. Implementation is further subdivided into promotion-preventive measures to ensure respect for human rights in the future-and protection-responses to violations that have occurred. The means and methods of implementation may be summarized in three forms of promotion and five forms of protection, all of which are relevant to the realization of the right to health. 


\section{A. Promotion (information and education, institutions, further standard-setting)}

Promotion of human rights is achieved through developing awareness, standard-setting and interpretation, and creation of national institutions. Awareness of human rights is a precondition to acting on them and is advanced though dissemination of knowledge (publications, information campaigns) and human rights education at all levels. Standard-setting refers to the drafting of human rights texts, at the UN level, principally the Human Rights Council and its predecessor Commission on Human Rights, as well as other bodies, such as the Commission on the Status of Women, and UN Specialized Agencies, such as the ILO and WHO, as well as the regional organizations (Council of Europe, OAS, OAU, Arab League, ASEAN) discussed above. These norms are interpreted by various international courts and treaty-monitoring bodies. The third preventive or promotional means of implementation is national institution-building, which includes improvements in the judiciary and law enforcement institutions and the creation of specialized bodies such as health officers in national commissions for human rights and human rights officers in ministries of health.

Thus, the institutions described in Part II above have contributed to the standard-setting, monitoring and interpretation of the right to health. Although, as Meier stresses, WHO "lost its human rights compass" from 1953-1973 (Meier 2010: 49), in recent years it has made modest advances in its promotional role, mainly through the work of the Department of Ethics and Social Determinants (formerly the Department of Ethics, Equity, Trade and Human Rights), such as the publication 25 Questions and Answers on Health and Human Rights (WHO, 2002) and The Right to Health Factsheet (WHO 2007a). Among the treaty bodies, the Committee on Economic Social and Cultural Rights has contributed significantly to the interpretative function of the promotional role through General Comment No. 14, discussed in Part III above. Another significant promotional function is carried out by the Special Rapporteur on the right of everyone to the enjoyment of the highest attainable standard of physical and mental health, whose mandate covers reporting on thematic topics, in addition to the protection functions discussed below. Other "thematic" rapporteurs deal with health-related issues, such as food, housing, and toxic waste.

\section{B. Protection (monitoring and evaluation, complaints and litigation)}

The protection of human rights involves a complex web of national and international mechanisms to monitor, judge, denounce, and coerce states, as well as provide relief to victims.

Monitoring compliance with international standards is carried out through the reporting and complaints procedures of the UN treaty bodies and regional human rights commissions and courts. States are required to submit reports, and the monitoring body-often guided by information provided by NGOs-examines progress and problems with a view to guiding the reporting country to do better. Several optional procedures allow individuals and groups (and sometimes other 
states) to petition these bodies for a determination of violations, including alleged violations of the ICESCR, once the optional protocol to that effect, which the General Assembly adopted and opened for signature in 2008, entered into force in May 2013. The quasi-judicial bodies, such as the Human Rights Committee (which monitors the ICCPR) or the African Commission on Human and Peoples Rights (which monitors the African Charter) utilize various forms of fact-finding and investigation and issue their views. Another monitoring mechanism is the Universal Periodic Review (UPR). All countries and all rights come under review of the UPR, including-surprising though this may be-the United States on the right to health, even though it has not ratified the ICESCR. The United States came under review in 2010, including with respect to its record on realizing the right to health, as did other reporting countries. (UN 2011)

Special procedures have been established in the UN through which working groups, independent experts and special rapporteurs are mandated to study countries or issues, including taking on cases of alleged violations, and report back on their findings and request redress from governments. Numerous right to health issues are raised by the country reports and urgent actions on individual communications, not only in those of the Special Rapporteur on the right to health but also in those of the procedures dealing with adequate housing; arbitrary detention; the sale of children; child prostitution and child pornography; enjoyment of a safe, clean, healthy and sustainable environment; extreme poverty; indigenous peoples; environmentally sound management and disposal of hazardous substances and wastes; violence against women; and safe drinking water and sanitation.

The second means of protection is adjudication of cases by fully empowered human rights courts, the main ones being the European Court of Human Rights, the Inter-American Court of Human Rights, and the African Court of Human and Peoples' Rights. At the national level, the trend of court cases invoking the right to health has been increasing (Byrne, 2009), although this trend has been criticized because "the successful litigants tend to come form economically and socially more advantaged groups." (Wolff, 2012: 38) Jonathan Wolff conjectures that this trend is "damaging health equity and cost-effectiveness." (Wolff, 2012: 38) The scale on which adjudication distorts health priorities is probably insignificant, and it is certainly consistent with the judicial function to determine that an individual right to health claim would impinge on the state's capacity to ensure the right to health for the population in general. For example, after deferring to state and medical authorities to reach rational decisions on the allocation of scarce resources (South Africa Constitutional Court, 1998), the South African Constitutional Court decided that the courts can determine whether state authorities have chosen the means that are reasonable to realize the right to health and order them to take additional steps if necessary. (South Africa Constitutional Court, 2002) More examples are analyzed in another chapter of this publication. (Cabrera and Ayala 2013)

Political supervision refers to the authority of bodies made up of representatives of states to adopt resolutions judging the policies and practices of 
states. The Commission on Human Rights and its successor Human Rights Council, the UN General Assembly, the Committee of Ministers of the Council of Europe, the Assembly of OAS, all have adopted politically significant resolutions denouncing governments for violations of human rights and demanding that they redress the situation. They often also call for compensation to the victims. This form of sanction may appear toothless since it is not backed up with coercive force; in practice, however, many governments-fearing reputational, economic or trade consequences - take quite seriously such political naming and shaming and go to considerable lengths to avoid it, including by improving their human rights performance with respect to the right to health.

The use of coercion is available only to the Security Council, which can use its powers under Chapter VII of the UN Charter to impose sanctions, cut off communications, create ad hoc criminal tribunals, and authorize the use of force by member states or deploy UN troops to put an end to a threat to international peace and security, which it has on occasion interpreted to include human rights violations. Human rights considerations were part of the use of Chapter VII in Haiti, Somalia, Bosnia, Iraq, Libya and other locations. This forceful means of protecting human rights is complex and dangerous and can have harmful health consequences, as has been the case with sanctions imposed on Haiti and Iraq (Marks 1999) or spread of cholera allegedly from infected peacekeepers in Haiti (Piarroux 2011). If used properly, forceful intervention can be a modern and legitimate form of the $19^{\text {th }}$ century doctrine of humanitarian intervention, according to which states use armed force to halt atrocities committed in another state while respecting the principles of necessity, proportionality, disinterestedness and collective action. NATO sought to employ such a doctrine in Kosovo in 1999 but, without the necessary authorization from the Security Council, engaged in a legitimate but illegal use of force. Each case of action (e.g., no-fly zones over Iraq since 1991) or inaction (e.g., Rwanda in 1994) regarding the use of armed force for human rights purposes has ethical and legal difficulties. Nevertheless, the legitimacy and legality of authorized force in response to a human rights crisis is now well established. (Marks and Cooper, 2010)

The final means of responding to human rights violations is through humanitarian relief or assistance. Provision of food, blankets, tents, medical and sanitary assistance, and other forms of aid saves lives and health of persons forcibly displaced often as a result of large-scale human rights violations or natural disasters. Refugees and internationally displaced persons come under the protection of the UN High Commissioner for Refugees (UNHCR), which deploys massive amounts of aid, along with the International Committee of the Red Cross, UNICEF, WFP, UNDP, the UN Office for the Coordination of Humanitarian Affairs and other agencies, as well as major NGOs like Oxfam, Care, and the International Rescue Committee. The complex relations with the host country and among the entities seeking to alleviate suffering in such humanitarian emergencies remain problematic, although there is little doubt that this method of implementing the right to health remains essential (Fidler, 2007; HHI, 2011) 


\section{Conclusion}

Every country in the world has accepted that human rights are universal and is bound by at least one treaty containing a provision on the right to health. All are challenged, in one way or another, to achieve progress with respect to this right. The normative content of the right to health has evolved from a contested definition of health and affirmation of it as a "fundamental right of all human beings" to treaty norms in the principal UN and regional human rights regimes with an impressive amount of interpretative work by treaty bodies, and regional and national judicial bodies. The content of the right is best understood as covering both the dimensions of the right that are the responsibility of the health system and the health-related human rights that focus on physical integrity, personal autonomy and social interactions.

The richness of the right to health and health-related human rights is of little value without effective means and methods of promotion and protection at the national and international levels. The twelve national studies in this publication illustrate the variety of national experience with both the recognition of the right and the means and methods of promotion and protection. Other chapters provide a rich tapestry of theory and practice of international litigation, health development as nation-strengthening, healthcare financing and health systems. Still other chapters address right-to-health approaches to access medical products, vaccines and technologies; to AIDS, malaria and TB; to diseases and conditions of poverty; to women's health; to genomics; to conflicts and disasters; to food and nutrition; to torture; and to prisons. It has been almost a half-century since the highest attainable standard of physical and mental health was affirmed as a human right in an international treaty, and this array of thematic issues is illustrative of how far the international community has come in that period.

Three final observations may be made in conclusion. First, there is no doubt-notwithstanding the failure of the US to ratify the ICESCR although it is bound by a least one other treaty affirming the right-about the status of the right to health among the internationally recognized human rights. One of the consequences has been the trend of national constitutions to contain a right to health provision following closely the wording of the international standard. (Kinney \& Clark, 2004) Second, the practice of treaty bodies, special procedures, and judicial bodies has significantly enriched the normative content of this right. Third, the moral and legal force of the human right to health as it has evolved has empowered activists to challenge certain major and politically-charged obstacles to global health, whether access to anti-retroviral treatment for HIV-affected individuals, effective tobacco control, inadequate access of vulnerable populations to healthcare facilities, conditions of detention in places like Guantánmo, and numerous other issues. In sum, the human right to health has evolved from a timid and confusing initial formulation in 1946 to a robust norm firmly anchored in national and international law but still in need of considerably more effort to reach the full potential of affecting profoundly the resource allocation and policy determination of health systems globally. 


\section{REFERENCES}

Philip Alston (Alston 1979), “The Untied Nations' Specialized Agencies and Implementation of the International Covenant on Economic, Social and Cultural Rights," Columbia Journal of Transnational Law, vol. 18, pp. 79-118 (1979).

Philip Alston (Alston 2001), “Peoples' Rights: Their Rise and Fall”, in Alston, Peoples' Rights, Oxford University Press, 2001, pp. 259-293

Gunilla Backman, Paul Hunt, Camila Jaramillo-Strauss, Belachew Mekuria Fikre, Caroline Rumble, Donald Pevalin, David Acurio Páez, Mónica Armijos Pineda, Ariel Frisancho, Duniska Tarco, Mitra Motagh, Dana Farcasanu, and Cristian Vledescu, "Health systems and the right to health: an assessment of 194 countries," The Lancet, vol. 372 (13 December 2008), pp. 2047-2085.

Lisa F. Berkman and Ichiro Kawachi, (eds.) Social Epidemiology, Oxford University Press, 2000.

Hazel Biggs. Euthanasia, Death with Dignity and the Law, Oxford, UK: Hart Publishing, 2001.

Michael Bochenek (2013), "Torture and Inhumane/Degrading Conditions," chapter 28 of this publication.

Sissela Bok, "Rethinking the definition of health," The International Encyclopedia of Public Health, 2008, vol. 6, pp. 590-597.

I. Byrne, "Enforcing the right to health: Innovative lessons from domestic courts," in A. Clapham and M. Robinson (eds), Realizing the Right to Health (Zurich: Rüffer \& Rub, 2009).

Oscar Cabrera and Ana Sumei Ayala (2013), "Advancing the Right to Health through International Litigation," chapter 2 of this publication.

Danwood Mzikenge Chirwa, African Regional Human Rights System, in Langford, 2008, pp. 323-338.

Luke Clements and Alan Simmons, European Court of Human Rights, in Langford, 2008, pp. 409-427.

Council of Europe, Secretariat of the European Social Charter (ESC 2009), Right to Health and the European Social Charter, March 2009 (available at http://www.coe.int/t/dGHl/monitoring/Socialcharter/Theme\%20factsheets/Facts heetHealth_en.pdf

Norman Daniels, Just Health. Meeting Health Needs Fairly, New York: Cambridge University Press, 2008. 
David Fidler, Governing catastrophes: security, health and humanitarian assistance, International Review of the Red Cross, Volume 89 Number 866 June 2007, pp. 247270.

Micheline Ishay, The History of Human Rights: From Ancient Times to the Globalization Era, With a New Preface, New York: Norton and Co., 2008.

Micheline Ishay (ed.), The Human Rights Reader: Major Political Essays, Speeches, and Documents from Ancient Times to the Present, Second Edition, New York: Routledge, 2007.

Sam Harris, The Moral Landscape. How Science Can Determine Human Values, New York, Free Press, 2010.

Harvard Humanitarian Initiative (HHI). Disaster Relief 2.0: The Future of Information Sharing in Humanitarian Emergencies. Washington, D.C. and Berkshire, UK: UN Foundation \& Vodafone Foundation Technology Partnership, 2011.

Jeanne Hersch (ed.), Birthright of Man, UNESCO, 1969. The French edition was published in 1968. A second edition was published in 1985.

Lynn Hunt, Inventing Human Rights: A History, New York: W. W. Norton \& Company, 2007.

Urfan Khaliq and Robin Churchill, The European Committee of Social Rights, in Langford, 2008, pp 453-474.

Eleanor D. Kinney \& Brian Alexander Clark, "Provisions for Health and Health Care in the Constitutions of the Countries of the World," Cornell International Law Journal, vol. 37 (2004), pp. 283-355.

Malcolm Langford, "The Justiciability of Social Rights: From Practice to Theory," in Malcolm Langford, Social Rights Jurisprudence. Emerging Trends in International and Comparative Law, New York: Cambridge University Press, 2008, pp. 1-45.

Paul Gordon Lauren, The Evolution of International Human Rights: Visions Seen, Philadelphia: University of Pennsylvania Press, 1998;

Hersch Lauterpacht, International Law and Human Rights, with an introduction by Isidore Silver. New York: Garland, 1950 (reprint 1973).

Joanne Mariner and Rebecca Schleifer (2013), "The Right to Health in Prisons," chapter 29 of this publication.

Stephen P. Marks, "Emerging Human Rights: A New Generation for the 1980's?" Rutgers Law Review, vol. 33, no. 2, 1981, pp. 435-452. 
Stephen P. Marks, Economic Sanctions as Human Rights Violations: Reconciling Political and Public Health Imperatives, American Journal of Public Health, October 1999, vol. 89, No. 10, pp., 1509-1513.

Stephen P. Marks, "The Past and Future of the Separation of Human Rights into Categories", Maryland Journal of International Law, vol. 24 (2009), pp. 208-241.

Stephen P. Marks and Nicolas Cooper, "The Responsibility to Protect: Watershed, or Old Wine in a New Bottle," Jindal Global Law Review (India), Volume 2, Issue 1, September 2010, p. 86-130.

Stephen P. Marks and Adriana Lee Benedict (2013), "Access to Medical Products, Vaccines and Medical Technologies," chapter 19 of this publication.

Benjamin Mason Meier, "Global Health Governance and the Contentious Politics of Human Rights: Mainstreaming the Right to Health for Public Health Advancement," Stanford Journal of International Law, .vol. 46 (2010), pp. 1-50.

Tara J. Melish, The Inter-American Commission on Human Rights, in Langford, 2008, pp. 339-371.

Johannes Morsink, The Universal Declaration of Human Rights: Origins, Drafting and Intent, Philadelphia, University of Pennsylvania Press, 1999.

Samuel Moyn, The Last Utopia: Human Rights in History, Cambridge MA: Belknap Press of Harvard University Press, 2012.

Jordan J. Paust, "The Human Right to Die with Dignity: A Policy-Oriented Essay," Human Rights Quarterly, Vol. 17, No. 3 (Aug., 1995), pp. 463-487.

Piarroux R, Barrais R, Faucher B, Haus R, Piarroux M, Gaudart J, et al. Understanding the cholera epidemic, Haiti. Emerg Infect Dis [serial on the Internet]. 2011 Jul [date cited]. http://dx.doi.org/10.3201/eid1707.110059囼

Kumanan Rasanathan, Johanna Norenhag, and Nicole Valentine, "Realizing human rights-based approaches for action on the social determinants of health," Health and Human Rights: An International Journal [Online], Vol. 12, No 2 (2010).

Eibe Riedel, The Human Right to Health: Conceptual Foundations, in Clapman A, Robinson M, Mahon C, and Jerbi S (eds.), Realizing the Right to Health, Swiss Human Rights Book, Vol. 3 (Zurich: Ruffer \& Rub, 2009).

Amartya Sen, "Why and how is health a human right?", The Lancet, vol. 372 (13 December 2008) p. 2010.

William A. Schabas, "International Law and Abolition of the Death Penalty", Washington and Lee Law Review, Vol. 55, Issue 3 (1998), pp. 797-846. 
South Africa Constitutional Court, 1998. Soobramoney v. Minister for Health, Constitutional Court of South Africa. 1 SA 765.

South Africa Constitutional Court, 2002. Minister of Health and Others v. Treatment Action Campaign and Others (2002), (10) BCLR 1033 (CC).

Victoria Sutton, “Conflicts, Disasters (naturally occurring and man-made)," chapter 26 in this publication.

John Tobin, The Right to Health in International Law, New York: Oxford University Press, 2012.

Brigit Toebes, "The Right to Health," in Asbjørn Eide, Catarina Krause and Allan Rosas, Economic, Social and Cultural Rights. A Textbook. $2^{\text {nd }}$ revised ed., The Hague, Netherlands: Kluwer Law International, 2001, pp. 169-190.

UN, 1945. Charter of the United Nations, 26 June 1945, 59 Stat. 1031, T.S. 993, 3 Bevans 1153, entered into force Oct. 24, 1945.

UN, 1955. Standard Minimum Rules for the Treatment of Prisoners, adopted by the First United Nations Congress on the Prevention of Crime and the Treatment of Offenders, held at Geneva in 1955, and approved by the Economic and Social Council by its resolutions 663 C (XXIV) of 31 July 1957 and 2076 (LXII) of 13 May 1977.

UN, 1984. United Nations, Economic and Social Council, U.N. Sub-Commission on Prevention of Discrimination and Protection of Minorities, Siracusa Principles on the Limitation and Derogation of Provisions in the International Covenant on Civil and Political Rights, Annex, UN Doc E/CN.4/1984/4 (1984).

UN, 1986. The Declaration on the Right to Development, 4 December 1986, UN Doc. A/ 41/RES/128.

UN, 1990. United Nations Committee on the Elimination of Discrimination Against Women (CEDAW), CEDAW General Recommendation No. 14: Female Circumcision, 1990, U.N. Doc A/45/38 and Corrigendum, available at:

http://www.unhcr.org/refworld/docid/453882a30.html [accessed 12 November 2012]

UN, 1994a. United Nations (ICPD 1994), Report of the International Conference on Population and Development, UN Doc A/CONF.171/13, Oct. 18, 1994).

UN, 1994b. Draft Principles On Human Rights and the Environment. E/CN.4/Sub.2/1994/9, Annex I (1994).

UN, 1998. United Nations (Rome Statute 1998), Rome Statute of the International Criminal Court, circulated as document A/CONF.183/9 of 17 July 1998 and 
corrected by procès-verbaux of 10 November 1998, 12 July 1999, 30 November 1999, 8 May 2000, 17 January 2001 and 16 January 2002.

UN, 2000. General Comment 14: The right to the highest attainable standard of health, UN doc. E/C.12/2000/4, 4 July 2000.

UN, 2003. United Nations Commission on Human Rights, 59th session, 2003, Report of the Special Rapporteur, Paul Hunt, submitted in accordance with Commission resolution 2002/31, UN Doc. E/CN.4/2003/58, 13 February 2003.

UN 2005. General Comment No. 17: The right of everyone to benefit from the protection of the moral and material interests resulting from any scientific, literary or artistic production of which he or she is the author. UN doc. E/C.12/GC/17, 12 January 2006.

UN, 2007. United Nations. Declaration on the Rights of Indigenous Peoples, UN Doc. A/61/RES/295, Annex, 13 September 2007.

UN, 2009. United Nations. Committee on Economic, Social and Cultural Rights. Guidelines on treaty-specific documents to be submitted by States parties under articles 16 and 17 of the International Covenant on Economic, Social and Cultural Rights. UN Doc. E/C.12/2008/2, ANNEX. 24 March 2009.

UN, 2010. United Nations. Human Rights Council. Report of the High Level Task Force on the Implementation of the Right to Development on its Ninth Session. UN Doc. A/HRC/15/WG.2/TF/2, Add. 1 (Consolidation of findings) and Add. 2 (Right to development criteria and operational sub-criteria).

UN 2011, Human Rights Council, Sixteenth session, Report of the Working Group on the Universal Periodic Review. United States of America, UN Doc. A/HRC/16/11, 4 January 2011.

Albert Verdoodt, , Naissance et signification de la Déclaration universelle des droits de l'homme, Louvain/Paris, Société d'études morales, sociales et juridiques/Editions Nauwelaerts, 1964, xiv, 356 pp.

Edward O. Wilson, The Social Conquest of Earth, New York, London: W. W. Norton \& Co., 2012.

Jonathan Wolff, The Human Right to Health, New York: W.W. Norton \& Co., 2012.

WHO, 1978. World Health Organization, Declaration of Alma-Ata. [Declaration of Alma-Ata Declaration from the International Conference on Primary Health Care, Alma-Ata, September 1978].

WHO, 2002. World Health Organization, 25 Questions and Answers on Health and Human Rights, Geneva: WHO, 2002. Available at http://whqlibdoc.who.int/hq/2002/9241545690.pdf 
World Health Organization (WHO 2007a), The right to health, Fact sheet $\mathrm{N}^{\circ} 323$, Geneva: WHO, August 2007, available at

http://www.who.int/mediacentre/factsheets/fs323/en/index.html

WHO 2007b, WHO global influenza preparedness plan. The role of WHO and recommendations for national measures before and during pandemics. Geneva, World Health Organization, 2005

(http://www.who.int/csr/resources/publications/influenza/WHO_CDS_CSR_GIP_2 005_5/en/index.html, accessed 1 October 2007).

WHO 2011. World conference on social determinants of health: meeting report, Rio de Janeiro, Brazil, 19-21 October 2011. Available at http://www.who.int/sdhconference/resources/wcsdh_report/en/index.html

Alicia Yamin (2013), “Women's Health and Human Rights," chapter 23 of this publication. 